\title{
The Morphological and Biochemical Components of Resistance in Field Bean against Pod Borers
}

\author{
K.M. Rashmi ${ }^{1}$, K.N. Muniswamy Gowda ${ }^{2}$, B. Tambat ${ }^{2}$, \\ N. Umashankar Kumar ${ }^{2}$ and L. Vijayakumar ${ }^{1}$ \\ ${ }^{1}$ College of Agriculture, VC form Mandya, India \\ ${ }^{2}$ College of Agriculture, Karekere, Hassan-573 225 \\ *Corresponding author
}

\section{A B S T R A C T}

Keywords

Morphological and biochemical traits,

Field bean, Pod

borers, Karnataka

Article Info

Accepted:

30 May 2020

Available Online:

10 June 2020
The morphological characters viz., pod length, pod width, pod wall thickness and trichome density in selected genotypes were studied and the correlation studies revealed that pod length showed positive correlation $(r=0.90)$ with pod damage. However, pod width showed non-significant association $(r=0.34)$ with the pod damage. While, pod trichome density and pod wall thickness $(r=-0.89 \&-0.88$, respectively) showed significant negative association with pod damage. The biochemical basis of resistance to pod borers in field bean genotypes revealed, the total phenols in pods of healthy and infested samples $(r=-0.92 \&-0.95$, respectively) showed a significant and negative relationship with per cent pod damage caused by pod borers. While, total sugars in healthy and infested pods ( $\mathrm{r}$ $=091 \& 0.94$, respectively), reducing sugars in healthy and infested pods $(r=0.89 \& 0.92$, respectively), crude proteins in healthy and infested pods ( $r=0.90 \& 0.96$, respectively) and amino acids in healthy and infested pods ( $\mathrm{r}=0.96 \& 0.91$, respectively) showed a significant positive association with per cent pod damage caused by pod borers.

\section{Introduction}

Lablab purpureus (L.), commonly called as field bean is one of the ancient leguminous crops cultivated mainly in southern parts of India. Though the crop is cultivated in almost all regions of Karnataka, it is highly grown as a mixed crop with finger millet and sorghum and to a smaller extent as a pure crop under rainfed as well as irrigated conditions. The damage by insect pests is considered as one of the major drawbacks in achieving the potential yield in field bean. Several of pests severely ravage the buds, flowers and developing seeds of bean crop resulting in crop loss. Govindan (1974) reported around 55 species of insects and one species of mite feeding on crop from seedling stage to harvest in Karnataka. 
Among sucking pests lablab bug, Coptosoma cribraria (Fabricius), Riptortus pedestris (Fabricius) and Nezara viridula (Linnaeus) occurred commonly in large numbers throughout the cropping period (Govindan,1974). The significant crop damage was attributed to the pod borer complex including Helicoverpa armigera (Hubner), Adisura atkinsoni (Moore), Maruca testulalis (Geyer), Etiella zinckenella (Treitschke), Cydia ptychora (Meyrick), Exelastis atomosa (Walshinghan), Sphenarches caffer (Zeller) and Lampides boeticus (Linnaeus) and Callosobruchus theobromae (L.) which are of considerable importance causing 80 per cent pod damage (Katagihallimath and Siddappaji, 1962). The inflorescence is attacked by several species of borers, of which E. atomosa, A. atkinsoni and $H$. armigera have been considered as major pests. Currently, spotted borer, $M$. vitrata is attaining a major pest status on Lablab varieties, blooming throughout the year. The seed yield loss caused by A. atkinsoni has reported to be more than 95 per cent (Chakravarthy, 1983) and pod damage, more than 49.43 per cent (Mallikarjunappa, 1989).

By considering the seriousness of damage caused by the pod borers it is felt necessary to find efficient and precise control measures. Since, L. purpureus is a vegetable crop, the eco-friendly suppression methods like the use of resistant varieties and application of needbased pesticides based on information of insect-pest dynamics should be adopted.

Host plant resistance remains the most effective tool in integrated pest management which is compatible with other methods of control without any additional cost to growers (Nadeem et al., 2010). Hence, the present research programme on Morphological and biochemical components of resistance in Field bean against pod borers was undertaken during 2017-18.

\section{Materials and Methods}

Out of the 30 genotypes screened 15 genotypes which sustained high and low levels of pod borer infestation were selected to study the morphological and biochemical factors associated with resistance and susceptibility. The pods of selected genotypes were collected at 20 days after pod initiation and subjected for further analysis of morphological and biochemical components. The pod samples of both healthy and infested pods were used for biochemical analysis.

\section{Morphological characters}

The morphological traits viz., pod length, pod width, trichome density and pod wall thickness were studied.

\section{Pod length}

Ten pods from each genotype on five randomly selected plants were used to assess the pod length with the help of graph paper and expressed in centimetre per pod. Mean length of pods were computed and correlated with the infestation of pod borers.

\section{Pod width}

The ten pods from each genotype on five randomly selected plants were collected to measure the pod width with the help of graph paper and expressed in centimetre per pod. Mean width of pod was computed and correlated with the infestation of pod borers.

\section{Trichome density}

The density of trichomes on pods was counted under ocular stage microscope as the method suggested by Jackai and Oghiakhe (1989). Trichomes were counted on ten pods from each genotype on five randomly selected plants by keeping a card board with $0.5 \mathrm{~cm} 2$ 
window on the pod samples to be examined and trichome density were recorded. And mean trichome density was computed and correlated with infestation of pod borers.

\section{Pod wall thickness}

Thickness of pod wall in ten pods from each genotype of five randomly selected plants was measured by using the vernier calipers and expressed in millimetre per pod. Mean pod wall thickness was computed and correlated with pod borer incidence.

\section{Biochemical components}

Biochemical constituents viz., total sugars, reducing sugars, total phenols, crude protein and total free amino acids in pod samples of different resistant and susceptible genotypes was done to establish the relationship between various biochemical contents and resistance or susceptibility.

\section{Extraction of plant tissues in alcohol}

Both infested and un-infested pod samples of five randomly selected plants from each genotype were collected and they were thoroughly washed with distilled water and dried under shade. One gram of pod sample pieces of all the genotypes were taken in separate conical flask and $15 \mathrm{ml}$ of 80 per cent ethanol was added. It was refluxed for 30 minutes on hot water bath. After boiling, the cooled extract and the pieces of tissues were ground thoroughly in a mortar with pestle in slight ethanol. The supernatant was decanted into another flask and residue was again re-extracted with small quantity of hot ethanol and decanted. This extract was filtered through Whatman No. 1 filter paper and made up to a known volume with 80 per cent ethanol. The ethanol part of (alcoholic) extract was stored in refrigerator at $4^{\mathrm{O}} \mathrm{C}$, and used for the estimation of total sugars, reducing sugars and phenols.

\section{Total phenols}

Estimation of total phenols in pods of the plant tissues were done by following FolinCiocalteau method suggested by Bray and Thorpe (1954).

\section{Preparation of reagents}

\section{Sodium carbonate solution}

Two gram of sodium carbonate was dissolved in $0.1 \mathrm{~N}$ Sodium hydroxide $(\mathrm{NaOH})$ and then the volume was made up to $100 \mathrm{ml}$ with $0.1 \mathrm{~N}$ $\mathrm{NaOH}$ solution.

\section{Folin-Ciocalteau reagent $(\mathrm{FCR})$}

Hundred grams of Sodium tungstate and 25 gm of sodium molybdate were dissolved in $700 \mathrm{ml}$ of water. Later, $50 \mathrm{ml}$ of 85 per cent Orthophosphoric acid and $100 \mathrm{ml}$ of concentrated Hydrochloric acid $(\mathrm{HCl})$ were added to it and boiled under reflux gently for about 10 hours. It was then cooled and 150 gm of lithium sulfate dissolved in $50 \mathrm{ml}$ of water was added to it. About 4-5 drops of liquid bromine was added to it. Then the mixture was boiled for about 15 minutes to remove excess of bromine. Later the solution was cooled and diluted to one liter with water. This reagent was stored in brown bottle. The normality of this reagent was determined by titrating against standard $\mathrm{NaOH}$ solution $(0.1$ $\mathrm{N})$. It was then diluted as per the need to make $2.0 \mathrm{~N}$. Just before use, one volume of this stock solution was diluted with one volume of water. The phenol content was estimated as follows.

One $\mathrm{ml}$ of Folin-Ciocalteau reagent was added to $1.0 \mathrm{ml}$ of the alcohol extract of the plant sample in a test tube followed by $2.0 \mathrm{ml}$ of 20 per cent sodium carbonate solution and the mixture was heated on a boiling water bath for exactly 1 minute. It was later cooled and made up to known volume $(20 \mathrm{ml})$ with 
distilled water. The blue color developed was measured in a spectrophotometer at $650 \mathrm{~nm}$. The standard curve was prepared using catechol and concentrations of phenols present in different samples of the genotypes were calculated using the standard curve and expressed as milligrams per gram of the plant sample.

\section{Total and reducing sugars}

To estimate total and reducing sugars, the method suggested by Somogyi (1952) was followed.

\section{Preparation of reagents A. Alkaline copper reagent}

\section{Solution A}

Twenty five grams of anhydrous Sodium carbonate, $25 \mathrm{~g}$ of Sodium potassium tartrate, $20 \mathrm{~g}$ of Sodium bicarbonate and $200 \mathrm{~g}$ of anhydrous Sodium sulphate were dissolved in $800 \mathrm{ml}$ of distilled water and diluted to one $1000 \mathrm{ml}$. The reagent was stored in a place where the temperature did not fall below 20 ${ }^{\circ} \mathrm{C}$.

\section{Solution B}

Fifteen grams of Copper sulphate was dissolved in a small volume of distilled water and one or two drops of concentrated Sulphuric acid and the volume made up to $100 \mathrm{ml}$ with distilled water. Twenty-four parts of solution A and one part of solution B were mixed to make the alkaline copper reagent solution just before use.

\section{Arseno molybdate reagent}

Twenty five grams of Ammonium molybdate was dissolved in $450 \mathrm{ml}$ of distilled water and $25 \mathrm{ml}$ of concentrated Sulphuric acid was then added and mixed. Three grams of Sodium ortho-arsenate dissolved separately in $25 \mathrm{ml}$ of distilled water was mixed with it and placed in an incubator at $30^{\circ} \mathrm{C}$ for $24-28$ hours. This reagent was stored in a glass stoppered brown bottle. Reducing and total sugars in the extracts were estimated by following the procedure of Somogyi (1952). For estimating the total sugars, hydrolysis of non-reducing sugars to reducing sugars will be done by adding one $\mathrm{ml}$ of $1.0 \mathrm{~N}$ hydrochloric acid to one $\mathrm{ml}$ of plant extract and were heated on a boiling water bath at 50 ${ }^{\circ} \mathrm{C}$ for 20 minutes. Later, it was cooled and a drop of phenolphthalein indicator solution was added. Then $1.0 \mathrm{~N}$ sodium hydroxide was added drop wise till the solution turned pink due to excess alkali. The excess alkali was re-neutralised with $0.1 \mathrm{~N}$ hydrochloric acid, which was added drop wise till the solution turned colourless and will be made up to known volume. One $\mathrm{ml}$ of Hydrolysate for total sugars and one ml of plant extract for reducing sugars was taken separately in boiling tubes to which one $\mathrm{ml}$ of freshly prepared alkaline copper reagent was added and boiled in a water bath for exactly 20 minutes. After cooling under running tap water, one $\mathrm{ml}$ of Arseno molybdate reagent was added with immediate mixing. The volume was made up to $15 \mathrm{ml}$ with distilled water and the blue color developed was read at $520 \mathrm{~nm}$. Suitable blanks prepared were used to adjust the light transmission to 100 per cent. A standard curve was prepared with glucose, which was used to calculate the unknown. The quantities were expressed as milligrams per gram of the plant sample.

\section{Crude protein}

The estimation of crude protein was done by following Micro-Kjeldahl method (Sadasivam and Manickam, 1996). This method gives an estimate of total nitrogen content present in the samples. Later this was converted to crude protein by using conversion factor. The method adopted was detailed here under. 


\section{Preparation of reagents}

\section{Sodium hydroxide solution}

About $400 \mathrm{~g}$ of sodium hydroxide was dissolved in one liter of distilled water.

Indicator solution: $20 \mathrm{~g}$ of methyl red and $100 \mathrm{mg}$ of bromocresol green were dissolved in 60- $\mathrm{ml}$ of ethanol.

Digestion mixture: $99 \mathrm{~g}$ K2SO4, $4.1 \mathrm{~g}$ of $\mathrm{HgO}$ and $0.8 \mathrm{~g}$ of $\mathrm{CuSO} 4$ were grounded in a mortar to prepare the digestion mixture.

Boric acid solution: $20 \mathrm{~g}$ of Boric acid was dissolved in $500 \mathrm{ml}$ of warm distilled water.

One gram of finely grounded dry plant sample was placed in a boiling tube to which a pinch of digestion mixture and $15 \mathrm{ml}$ of concentrated $\mathrm{H}_{2} \mathrm{SO}_{4}$ was added. These tubes were kept for digestion in Kjel-Plus (KPS012L) provided with vacuum pump for about one hour. This was later allowed to cool and transferred to distillation apparatus. Conical flask of capacity $100 \mathrm{ml}$ containing $25 \mathrm{ml}$ of 4 per cent boric acid with a few drops of mixed indicator was placed under the condenser, the tip of which was dipped in boric acid solution. A required amount of $\mathrm{NaOH}$ solution was added to the sample. Later the distillate was titrated against $0.02 \mathrm{~N} \mathrm{H} 2 \mathrm{SO} 4$ till the original pink-red color was restored.

The amount of nitrogen present in a given sample was calculated by the following formula:

$\mathrm{N}(\%)=$

Titre value $\times$ Normality of acid $\times 0.014 \times$ volume of digested sample

Weight of the sample $(\mathrm{g}) \times$ Aliquot taken
Crude protein was calculated by the formula: Crude protein $(\%)=\mathrm{N}(\%) \times 6.25$

Then, the crude protein content in the sample was expressed as per cent.

Population dynamics of major pod bore

\section{Total free amino acid}

The amount of total free amino acid present in the samples was estimated by following Ninhydrin method developed by Moore and Stein (1948).

\section{Preparation of reagents}

0.2 M Citrate buffer (pH 5.0): $20.5 \mathrm{ml}$ of $0.1 \mathrm{M}$ citric acid $(21.01 \mathrm{~g}$ in $1000 \mathrm{ml})$ and $29.5 \mathrm{ml}$ of $0.1 \mathrm{M}$ sodium citrate solution $(29.41 \mathrm{~g}$ in $1000 \mathrm{ml}$ ) were diluted to $100 \mathrm{ml}$.

Ninhydrin reagent: $0.8 \mathrm{~g}$ of stannous chloride $(\mathrm{Sncl} 2.2 \mathrm{H} 2 \mathrm{O})$ was dissolved in 500 $\mathrm{ml}$ of $0.2 \mathrm{~m}$ citrate buffer ( $\mathrm{pH} 5.0$ ). To this solution, $20 \mathrm{~g}$ ninhydrin in $500 \mathrm{ml}$, methyl cellulose ( 2 methyl ethanol) was added.

Diluent solvent: Mix equal volumes of water and n-propanol.

Stock standard leucine solution: $50 \mathrm{mg}$ of leucine was added to $50 \mathrm{ml}$ of water.

Working standard: $10 \mathrm{ml}$ of stock leucine solution was diluted to $100 \mathrm{ml}$ of water. $1 \mathrm{ml}$ of alcohol free extract of plant samples was pipetted out into separate test tubes and one mille liter of ninhydrin reagent was added and mixed well. Then the volume of each test tube was made up to $2 \mathrm{ml}$ by using distilled water. All the test tubes are heated in a boiling water bath for 20 minutes. Then $5 \mathrm{ml}$ of diluent solution was added while the test tubes were still on the water bath and mixed well. Meanwhile, a blank was prepared by mixing 1 
$\mathrm{ml}$ of 80 per cent ethanol and $1 \mathrm{ml}$ of ninhydrin reagent, the volume was made up to $2 \mathrm{ml}$. After 15 minutes of boiling, tubes were cooled under running tap water and absorbance of purple colour was measured against reagent blank at $570 \mathrm{~nm}$ using spectrophotometer. The amount total free amino acids present in the plant samples were calculated from the standard curve and expressed in $\mathrm{mg} / \mathrm{g}$.

\section{Results and Discussion}

Morphological Parameters: The data pertaining to various morphological characters like pod length, pod width, pod wall thickness and trichome density in selected genotypes are presented in Table 1.

\section{Pod length}

There was a significant variation among the genotypes with respect to pod length and the pod length varied between 4 to $5.32 \mathrm{~cm}$. longer pods were noticed in susceptible genotypes compared to resistant (Table 1). Also, the relationship between pod length and pod damage by pod borers revealed a significant positive $(r=0.90)$ association (Table 3).

\section{Pod width}

There was a significant variation among the genotypes with respect to pod width. Among the genotypes, the pod width varied from 1.40 to $1.90 \mathrm{~cm}$ (Table 1). However, the correlation between pod width and pod damage showed non-significant positive association $(r=0.34)$ (Table 3$)$.

\section{Pod trichome density}

Among the genotypes, the number of trichome on pods showed a significant variation and varied from 198 to $428 / 0.5 \mathrm{~cm} 2$
(Table 1). The maximum number of trichome was recorded in resistant genotype, GL-661 with 428/ $0.5 \mathrm{~cm} 2$. While, minimum was recorded in susceptible genotype HA-4 (198/ $\left.0.5 \mathrm{~cm}^{2}\right)$. The correlation studies revealed a significant negative association with the per cent pod damage and number of trichome on pods $(\mathrm{r}=-0.89)($ Table 3$)$.

\section{Pod wall thickness}

The pod wall thickness showed a significant variation among the genotypes. The genotype GL-661 recorded maximum pod wall thickness $(0.70 \mathrm{~mm})$ and was minimum in HA-4 $(0.49 \mathrm{~mm})$ (Table 1$)$. The correlation studies to establish the possible association between Pod wall thickness and per cent pod damage revealed a significant negative association $(\mathrm{r}=-0.88)$ (Table 3$)$.

The present findings on morphological parameters of resistance in field bean against pod borers are in close agreement with Kumar et al., (2015) who reported that among morphological constituents of pigeon pea, pod length and pod width were positively correlated with per cent pod damage, whereas pod wall thickness and trichome density had significant negative correlation with pod fly damage. Kamakshi et al., (2008) studied plant parameters in nineteen selected genotypes of field bean and reported that pod length and pod width were the least in a resistant genotype compared to susceptible. But in the present study, it was found that pod width did not have any significant effect on pod borer damage.

Rana et al., (2017) also reported that pod wall thickness and pod trichome density are negatively correlated with pod damage in pigeon pea. Moudgal et al., (2008), Salimath et al., (2008) and Sunitha et al., (2008) also reported that trichome density on pods found to offer resistance against pod borers. 


\section{Biochemical components}

The data pertaining to various biochemical components like total phenols, total sugars and reducing sugars, crude protein and free amino acids content present in both healthy and infested pod sample of selected genotypes of field bean and the relationship between these biochemical components and pod damage is presented here under (Table 2 and 4).

\section{Total phenols}

The phenol content among 15 genotypes assessed was significantly different. The phenol content of susceptible genotype HA-4 was low $(1.46 \mathrm{mg} / \mathrm{g})$, while relatively high phenol content was present in cultivars GL$661(2.79 \mathrm{mg} / \mathrm{g})$, which recorded low percent pod damage. The phenol content in infested samples was high compared to healthy pods and varied between 1.56-3.59 mg/ g (Table 2 ). The correlation between the pod damage and phenol content in both healthy $(r=-0.92)$ and infested $(r=-0.95)$ pods of different genotypes was negative and significant, indicating that increase in phenol content resulted in less pod damage (Table 4).

The present findings are in conformity with Kamakshi et al., (2008) who reported a significant negative relationship between pod damage and phenol content in field bean genotypes. Anantharaju and Muthiah (2008) and Kumar et al., (2015) also reported that higher phenol content in pods offered resistance to pod borers in pigeon pea. Similarly, Tiwari et al., (2017) also observed negative correlation of pest damage with phenol content and reported that phenol content in infested pods were high compared to healthy pods of pigeon pea. Phenols are plant secondary metabolites and they may not contribute to growth or reproduction directly but they often contribute to plant defense.
Phenols are found to be associated with repellence, or adverse effects on physiology insects. The increase in phenol content in infested pods may be due to plant's defence response to insect attack.

\section{Total sugars}

The total sugar content in pod samples of different genotypes varied significantly and varied from 2.02 to 3.91 per cent. The genotype HA-4 had high pod damage (51.4 $\%)$ and possessed relatively higher sugar content (3.91\%), while the genotype GL-661 suffered least pod damage $(11.67 \%)$ by pod borer and possessed significantly lower sugar content $(2.02 \%)$. The sugar content in infested samples was low compared to healthy pods and varied between 1.75 to 3.52 $\%$ (Table 4). The correlation between total sugars in healthy $(\mathrm{r}=0.91)$ and infested $(\mathrm{r}=$ 0.94) samples and pod damage was positive and significant, indicating that higher the sugar content higher is the infestation (Table $4)$.

Sugars play a vital role in insect growth, development, survival and reproduction. Halder and Srinivasan (2007) and Kumar et al., (2015) reported that Highest amount of total sugar were present in highly susceptible cultivar as compared to highly resistant cultivar. Tiwari et al., (2017) also proved that positive association exist between total sugars and pod damage in pigeon pea and total sugar content decreased in infested pods compared to healthy. So present findings are in agreement with these earlier reports.

\section{Total reducing sugars}

The total reducing sugar content in pod samples of different genotypes showed significant variation and varied from 0.57 to 1.62 per cent. The genotype HA-4 had high pod damage $(51.4 \%)$ and possessed relatively 
higher reducing sugar content $(1.62 \%)$, while the genotype GL-661 suffered least pod damage (11.67 \%) by pod borer and possessed significantly lower reducing sugar content $(0.57 \%)$. The reducing sugar content in infested samples was low compared to healthy pods and varied between 0.48 to 1.33 $\%$ (Table 2). The correlation between reducing sugars in healthy $(\mathrm{r}=0.89)$ and infested $(r=0.92)$ samples and pod damage was positive and significant, indicating that higher the sugar content higher is the infestation (Table 4). The present findings are in concurrent with Kamakshi et al., (2008) who claimed that higher reducing sugar content were present in highly susceptible cultivar as compared to highly resistant cultivar. Halder and Srinivasan (2007) and Kumar et al., (2015) proved a significant positive relationship between pod damage and reducing sugar content.

Table.1 Morphological characters in the pods of different selected field bean genotypes screened against pod borers

\begin{tabular}{|c|c|c|c|c|c|c|}
\hline & enotypes & \multirow{2}{*}{\begin{tabular}{|l}
$\begin{array}{l}\text { Pod damage } \\
(\%)\end{array}$ \\
$11.67(19.97)$
\end{tabular}} & \multirow{2}{*}{$\begin{array}{c}\begin{array}{c}\text { Pod } \\
\text { length } \\
\text { (cm) }\end{array} \\
4.00\end{array}$} & \multirow{2}{*}{$\begin{array}{r}\begin{array}{c}\text { Pod } \\
\text { width } \\
\text { (cm) }\end{array} \\
1.45\end{array}$} & \multirow{2}{*}{$\begin{array}{c}\begin{array}{c}\text { Pod } \\
\text { trichome } \\
\text { density }\end{array} \\
\left.\text { (No. } / \mathbf{0 . 5} \mathbf{c m}^{2}\right) \\
428.00\end{array}$} & \multirow{2}{*}{$\begin{array}{c}\text { Pod wall } \\
\text { thickness } \\
\text { (mm) }\end{array}$} \\
\hline $\mathbf{R}$ & GL-661 & & & & & \\
\hline & GL-12 & $14.38(22.27)$ & 4.18 & 1.73 & 405.00 & 0.69 \\
\hline & GL-418 & $16.17(23.71)$ & 4.70 & 1.48 & 390.00 & 0.66 \\
\hline & GL-438 & $17.11(24.43)$ & 4.23 & 1.73 & 333.50 & 0.65 \\
\hline & GL-382 & 17.99 (25.09) & 4.71 & 1.57 & 305.00 & 0.58 \\
\hline \multirow[t]{5}{*}{ MR } & GL-142 & $26.01(30.63)$ & 4.79 & 1.40 & 306.00 & 0.64 \\
\hline & GL-372 & 26.89 (31.22) & 4.81 & 1.82 & 290.00 & 0.57 \\
\hline & GL-252 & 26.98 (31.28) & 4.83 & 1.75 & 275.00 & 0.56 \\
\hline & GL-360 & $28.59(32.31)$ & 5.10 & 1.49 & 279.50 & 0.55 \\
\hline & GL-337 & 29.39 (32.82) & 4.94 & 1.55 & 263.00 & 0.57 \\
\hline $\mathbf{S}$ & GL-66 & 34.97 (36.25) & 5.15 & 1.90 & 259.50 & 0.55 \\
\hline \multirow[t]{4}{*}{ HS } & Ha-3 & 46.83 (43.17) & 5.26 & 1.73 & 256.00 & 0.54 \\
\hline & local & $47.91(43.80)$ & 5.29 & 1.54 & 242.30 & 0.53 \\
\hline & GL-10 & 48.21 (43.97) & 5.31 & 1.80 & 218.00 & 0.51 \\
\hline & На-4 & $51.40(45.80)$ & 5.32 & 1.72 & 198.00 & 0.49 \\
\hline & SE $\mathbf{m} \pm$ & 1.17 & 0.18 & 0.08 & 14.73 & 0.02 \\
\hline \multicolumn{2}{|c|}{ CD @ 5\% } & 3.54 & 0.55 & 0.25 & 44.68 & 0.06 \\
\hline
\end{tabular}

R- Resistant; MR- Moderately Resistant; S- Susceptible; HS- Highly Susceptible Figures in the parentheses indicate arc sine transformed values 
Table.2 Biochemical constituents in healthy and infested pods of selected field bean genotypes screened against pod borers

\begin{tabular}{|c|c|c|c|c|c|c|c|c|c|c|c|c|}
\hline \multirow{2}{*}{\multicolumn{2}{|c|}{ Genotypes }} & \multirow{3}{*}{$\begin{array}{c}\begin{array}{c}\text { Pod } \\
\text { damage } \\
(\%)\end{array} \\
11.67 \\
(19.97)\end{array}$} & \multicolumn{2}{|c|}{$\begin{array}{c}\text { Total } \\
\text { phenols } \\
\text { (mg/g) }\end{array}$} & \multicolumn{2}{|c|}{$\begin{array}{c}\text { Total sugars } \\
(\%)\end{array}$} & \multicolumn{2}{|c|}{$\begin{array}{c}\text { Total } \\
\text { reducing } \\
\text { sugars }(\%)\end{array}$} & \multicolumn{2}{|c|}{$\begin{array}{c}\text { Crude } \\
\text { protein }(\%)\end{array}$} & \multicolumn{2}{|c|}{ TFA $(\%)$} \\
\hline & & & H & I & $\mathbf{H}$ & I & H & I & $\mathbf{H}$ & I & $\mathbf{H}$ & I \\
\hline \multirow[t]{5}{*}{$\mathbf{R}$} & $\begin{array}{l}\text { GL- } \\
661\end{array}$ & & 2.79 & 3.59 & 2.02 & 1.75 & 0.57 & 0.48 & 19.63 & 18.98 & 0.12 & 0.20 \\
\hline & $\begin{array}{c}\text { GL- } \\
12\end{array}$ & $\begin{array}{c}14.38 \\
(22.27)\end{array}$ & 2.63 & 3.26 & 2.37 & 1.93 & 0.60 & 0.59 & 22.00 & 21.25 & 0.17 & 0.18 \\
\hline & $\begin{array}{l}\text { GL- } \\
418\end{array}$ & $\begin{array}{c}16.17 \\
(23.71)\end{array}$ & 2.41 & 3.19 & 2.55 & 2.21 & 0.62 & 0.61 & 25.25 & 24.98 & 0.42 & 0.47 \\
\hline & $\begin{array}{l}\text { GL- } \\
438\end{array}$ & $\begin{array}{c}17.11 \\
(24.43)\end{array}$ & 2.72 & 3.46 & 2.45 & 2.31 & 0.66 & 0.51 & 25.38 & 24.70 & 0.51 & 0.52 \\
\hline & $\begin{array}{l}\text { GL- } \\
382\end{array}$ & $\begin{array}{c}17.99 \\
(25.09)\end{array}$ & 2.36 & 3.06 & 2.65 & 2.33 & 0.67 & 0.65 & 27.00 & 25.88 & 0.61 & 0.64 \\
\hline \multirow[t]{5}{*}{ MR } & $\begin{array}{l}\text { GL- } \\
142\end{array}$ & $\begin{array}{c}26.01 \\
(30.63)\end{array}$ & 2.30 & 2.82 & 2.82 & 2.54 & 0.67 & 0.64 & 28.75 & 28.13 & 0.69 & 0.73 \\
\hline & $\begin{array}{l}\text { GL- } \\
372\end{array}$ & $\begin{array}{c}26.89 \\
(31.22)\end{array}$ & 2.44 & 2.99 & 2.76 & 2.42 & 0.71 & 0.68 & 29.00 & 28.40 & 0.81 & 0.86 \\
\hline & $\begin{array}{l}\text { GL- } \\
252\end{array}$ & $\begin{array}{c}26.98 \\
(31.28)\end{array}$ & 2.04 & 2.50 & 3.34 & 2.62 & 0.82 & 0.75 & 28.88 & 28.15 & 1.02 & 1.03 \\
\hline & $\begin{array}{l}\text { GL- } \\
360\end{array}$ & $\begin{array}{c}28.59 \\
(32.31)\end{array}$ & 2.01 & 2.54 & 3.32 & 2.60 & 0.86 & 0.84 & 29.78 & 28.50 & 1.03 & 1.12 \\
\hline & $\begin{array}{l}\text { GL- } \\
337\end{array}$ & $\begin{array}{c}29.39 \\
(32.82)\end{array}$ & 1.95 & 2.38 & 3.27 & 2.63 & 0.93 & 0.89 & 30.63 & 29.48 & 1.33 & 1.41 \\
\hline $\mathbf{S}$ & $\begin{array}{c}\text { GL- } \\
66\end{array}$ & $\begin{array}{c}34.97 \\
(36.25)\end{array}$ & 1.91 & 2.33 & 3.44 & 2.93 & 0.96 & 0.92 & 31.88 & 30.88 & 1.67 & 1.73 \\
\hline \multirow[t]{4}{*}{ HS } & Ha-3 & $\begin{array}{c}46.83 \\
(43.17)\end{array}$ & 1.89 & 2.25 & 3.38 & 2.91 & 1.09 & 0.95 & 32.25 & 31.73 & 1.71 & 1.72 \\
\hline & Local & $\begin{array}{c}47.91 \\
(43.80)\end{array}$ & 1.80 & 1.84 & 3.45 & 3.32 & 0.98 & 0.93 & 32.38 & 31.63 & 2.09 & 2.11 \\
\hline & $\begin{array}{c}\text { GL- } \\
10\end{array}$ & $\begin{array}{c}48.21 \\
(43.97)\end{array}$ & 1.68 & 2.10 & 3.59 & 3.43 & 1.47 & 1.04 & 32.88 & 32.13 & 2.30 & 2.33 \\
\hline & На-4 & $\begin{array}{c}51.40 \\
(45.80)\end{array}$ & 1.46 & 1.56 & 3.91 & 3.52 & 1.62 & 1.33 & 33.00 & 32.63 & 2.82 & 2.92 \\
\hline \multicolumn{2}{|c|}{ SE $m \pm$} & 1.17 & 0.08 & 0.09 & 0.13 & 0.10 & 0.07 & 0.05 & 0.88 & 0.89 & 0.05 & 0.05 \\
\hline \multicolumn{2}{|c|}{ CD @ 5\% } & 3.54 & 0.25 & 0.27 & 0.39 & 0.31 & 0.21 & 0.14 & 2.66 & 2.69 & 0.15 & 0.14 \\
\hline
\end{tabular}

H-Healthy and I- Infested, Figures in the parentheses indicate arc sine transformed values 
Table.3 Relationship between morphological parameters and pod damage due to pod borers

\begin{tabular}{|l|c|}
\hline Morphological parameters & Correlation coefficient (r) \\
\hline Pod length $(\mathbf{c m})$ & $0.90^{* *}$ \\
\hline Pod width $(\mathbf{c m})$ & 0.34 \\
\hline Pod trichome density $\mathbf{( N o} \mathbf{~ / 0 . 5 ~ c m 2 )}$ & $-0.89 * *$ \\
\hline Pod wall thickness $(\mathbf{m m})$ & $-0.88^{* *}$ \\
\hline ** Significant at $\mathrm{P} \leq 0.01$ & \\
\hline
\end{tabular}

Table.4 Relationship between biochemical components and pod damage due to pod borers

\begin{tabular}{|c|c|c|}
\hline \multirow[t]{2}{*}{ Biochemical Parameters } & \multicolumn{2}{|c|}{ Correlation coefficient (r) } \\
\hline & Healthy & Infested \\
\hline Total phenols (mg/g) & $-0.92 * *$ & $-0.95 * *$ \\
\hline Total sugars (\%) & $0.91 * *$ & $0.94 * *$ \\
\hline Reducing sugars (\%) & $0.89 * *$ & $0.92 * *$ \\
\hline $\begin{array}{l}\text { Total free amino acids } \\
(\%)\end{array}$ & $0.96 * *$ & $0.91 * *$ \\
\hline Crude protein (\%) & $0.90 * *$ & $0.96 * *$ \\
\hline
\end{tabular}

\section{Crude protein}

The Crude protein content in pod samples of different genotypes varied significantly and varied from 19.63 to 33 per cent. Wherein, susceptible genotypes recorded significantly higher crude proteins compared to resistant genotypes. The crude proteins in the pods of susceptible and resistant genotypes varied between 32.25 to 33 per cent and 19.63 to 27 per cent, respectively. The susceptible genotype HA-4 recorded significantly more amount of crude proteins $(33 \%)$ and significantly less amount of crude proteins $(19.63 \%)$ was recorded in resistant genotype GL-661. The crude protein content in infested pod samples was low compared to healthy pods and varied between 18.98 to 32.63 per cent (Table 2). The correlation between crude protein in healthy $(r=0.90)$ and infested $(r=$ 0.96) samples and pod damage was positive and significant, indicating that higher the sugar content higher is the infestation (Table 4).
Similarly, studies by Kamakshi et al., (2008) and Sujithra and Srinivasan (2012) manifested that proteins exhibited significant positive association with pod borer incidence in field bean genotypes. Tiwari et al., (2017) also reported that positive association exist between protein and pod damage in pigeon pea and protein content decreased in infested pods compared to healthy. Anantharaju and Muthiah (2008) and Kumar et al., (2015) also expounded that low protein content in pigeon pea genotypes offered resistance to pod borers.

\section{Total free amino acids}

The total free amino acids in the pods of resistant genotypes varied from 0.12 to 0.61 per cent and in susceptible genotypes it varied from 1.71 to 2.82 per cent. The susceptible genotype HA-4 contained significantly high amount of TFA $(2.82 \%)$ and significantly low amount $(0.12 \%)$ was found in the resistant genotype GL-661. The TFA content in infested samples was higher compared to 
healthy pods and varied between 0.20 to 2.92 per cent (Table 2). The difference in TFA among genotypes were significant and showed positive correlation with percent pod damage in both healthy $(\mathrm{r}=0.96)$ and infested $(\mathrm{r}=0.91)$ pod samples (Table 4$)$.

The present results are in close concurrence with the findings of Kumar et al., (2015) who reported that total free amino acids in the pod walls of pigeon pea showed positive correlation with pod fly damage. Similarly, Anantharaju and Muthiah (2008) showed that free amino acids content were low in resistant genotypes compared to susceptible genotypes. Halder and Srinivasan (2007) also proved that total free amino acids in the urd bean genotypes showed positive association with M. vitrata infestation. Tiwari et al., (2017) manifested that free amino acids in infested pods were high compared to healthy pods of pigeon pea.

\section{Acknowledgement}

Authors thankful to College of Agriculture, VC form, Mandya for providing field and lab facility. Also thank Dr. S. Ramesh, UAS, GKVK, Bangalore for providing seed material.

\section{References}

Anantharaju, P. and Muthiah, A. R., 2008. Biochemical components in relation to pest incidence of pigeon pea spotted pod borer (Maruca vitrata) and blister beetle (Mylabris spp.). Leg. Res., 31(2): 87-93.

Bray, H. G. and Thorpe, W. V., 1954. Analysis of phenolic compounds of interest in metabolism, Methods in Biochemical Analysis, 52: 1-27.

Chakravarthy, A. K., 1983. Relative abundance of field bean (Lablab niger Medick) pod borers and distribution patterns of the borer, Adisura atkinsoni
Moore. Insect Sci. Applic., 4(4): 401406.

Govindan, R., 1974. Insects of the field bean, Lablab niger var. lignosus Medikus with special reference to the biology and ecology of the pod borer, Adisura atkinsoni Moore (Lepidoptera: Noctuidae). M. Sc. (Agri.) Thesis, University of Agricultural Sciences, Bangalore, p.1-34.

Halder, J. and Srinivasan, S., 2007. Biochemical Basis of Resistance against Maruca vitrata (Geyer) in urd bean. Ann. Pl. Protec. Sci. 15(2): 287-290.

Jackai, L. E. N. and Oghiakhe, S., 1989. Pod wall trichomes and resistance of two wild cowpea, Vigna vexillata accessions to Maruca testulalis (Geyer) (Lepidoptera: Pyralidae) and Clavigralla tomentosicollis Stal (Hemiptera: Coreidae). Bull. Entomo. Res., 79: 595605.

Kamakshi, N., Srinivasan, S. and Muralikrishna, T. 2008. Influence of biochemical constituents of pod borer complex in selected field bean genotypes. Ann. Pl. Protec., 16(2): 302-305.

Katagihallimath, S. S. and Siddappaji, C., 1962. Observations on the incidence of lepidopteran pod borers of Dolichos lablab and the results of preliminary insecticidal trails to control them. $2^{\text {nd }}$ All India Congress of Zoology, pp. 59.

Kumar, G. S., Krishna, T. M., Prasanthi, L., Sudhakar, P. and Devaki, K., 2015. Morphological and biochemical traits associated with resistance to pod fly, Melanagromyza obtusa (malloch) in pigeonpea. Int. J. Appl. Biol, Pharm. Technol., 6(3): 134-141.

Mallikarjunappa, 1989. Field bean pod borer complex with reference to germplasm screening, life table, action threshold, crop loss and chemical control of Adisura atkinsoni. Ph. D. Thesis, University of Agricultural Sciences, Bangalore, p. 1- 
15.

Moore, S. and Stein, W. H., 1948. Photometric ninhydrin method for use in the chromatography of amino acids method, J. Biol. Chem., 176: 367-388.

Moudgal, R. K., Lakra, R. K., Dahiya, B. and Dhillon, M. K., 2008. Physicochemical traits of Cajanus cajan (L.) Millsp. Pod wall affecting Melanagromyza obtusa (Malloch) damage. Euphytica, 161(3): 429-436.

Nadeem, S., Shafique, M., Hamed, M., Atta, B.M. and Shah, T.M., 2010. Evaluation of advanced chickpea genotypes for resistance to pod borer, Helicoverpa Armigera (Hubner) (Lepidoptera: Noctuidae). Pak. J. Agri. Sci., 47(2): 132135.

Rana, N., Ganguli, J., Agale., S. and Joshi, B., 2017. Role of morphological characters offering resistance/ susceptibility of pigeon pea genotypes to pod borer complex. Agric. Update, 12(3): 641-647.

Sadasivam, S. and Manickam, A., 1996. Biochemical methods, New Age Int: New Delhi.
Salimath, P. M., Sharma, H. C. and Kumar, A., 2008, Biophysical basis of host plant resistance to pod borer (Helicoverpa armigera Hubner) in Pigeon pea. Ann. Plant Protec. Sci., 32(3): 20-23.

Sujithra, M. and Srinivasan, S., 2012. Biophysical and bio-chemical factors influencing plant resistance in pod borers on field bean, Lablab purpureus var. lignosus Medikus. Ann. Plant Protec. Sci., 20(2): 329-333.

Sunitha, V., Rao, G. V. R., Lakshmi, K. V., Saxena, K. B., Rao, V. R. and Reddy, Y. V. R., 2008. Morphological and biochemical factors associated with resistance to Maruca vitrata (Lepidoptera: Pyralidae) in shortduration pigeon pea. Int. J. Trop. Ins. Sci., 28(1): 45-62.

Tiwari, S., Yadav, S. and Nadaf, A., 2017. Influence of some biochemical components on the incidence of Maruca vitrata (Geyer) on short duration pigeon pea Cajanus cajan (L.) Mill sp. Int. J. Chem. Stud., 5(4): 1339-1341.

\section{How to cite this article:}

Rashmi, K.M., K.N. Muniswamy Gowda, B. Tambat, N. Umashankar Kumar and Vijayakumar, L. 2020. The Morphological and Biochemical Components of Resistance in Field Bean against Pod Borers. Int.J.Curr.Microbiol.App.Sci. 9(06): 3894-3905.

doi: https://doi.org/10.20546/ijcmas.2020.906.459 